\title{
DA COMPETÊNCIA DAS AGÊNCIAS REGULADORAS PARA INTERVIR NA MUDANÇA DE CONTROLE DAS EMPRESAS CONCESSIONÁRIAS
}

ARNOLDO WALD

I. Introdução - II. A Natureza Jurídica da Concessão: Um Contrato Especial de Direito Público "Intuitu Personae" - III. Atos Societários e Atos Biface - IV. Da Atuação e Intervenção do Poder Concedente - V. As Transformações Societárias das Concessionárias no Setor de Telecomunicações - VI. Problemas Societários e Intervenção da Agência Reguladora - VII. O Interesse da União - VIII. A Diferença entre o "Amicus Curiae" e a Assistência Especialíssima (prevista pela lei $n^{\circ}$ 9.649/67) - IX. A Competência da Justiça Federal - X. Conclusão.

\section{Introduçāo}

1. As recentes alterações de fato e de direito na estruturação societária de diversas empresas concessionárias prestadoras de serviços públicos, nos setores de telecomunicações, energia elétrica, gás e petróleo, ensejaram mudanças efetivas no controle acionário das mesmas. Por outro lado, às agências reguladoras foi legalmente atribuído o poder de fiscalização sobre tais operações, fato que gerou inúmeros questionamentos. A discussão se refere à extensão destes poderes e a possibilidade de utilizar medidas judiciais ou administrativas para prevenir ou remediar as situações ilegais ou irregulares, inclusive decorrentes da insolvência dos controladores.

2. Indaga-se se devem as agências reguladoras exercer sobre as concessionárias controle administrativo espontâneo, de ofício, em face do conhecimento inequívoco das alterações que possam ocorrer no controle das mesmas, inclusive interna corporis, ou, se instada a comparecer em processos judiciais que discutam tais situações, teriam as agências competência para atuar nesse âmbito ou deveriam esperar possivelmente as decisões do Poder Judiciário. 
3. Para encaminhar tais questōes, é imprescindivel a análise do âmbito das competências da agência, dos compromissos e obrigações das concessionárias. incluindo as consequiências da não preservação das condições de habilitação e qualificação requeridas por ocasião da licitação, em especial no que se refere ao controle acionário das mesmas, e ainda da natureza dos atos abrangidos por tais operações.

\section{A Natureza Jurídica da Concessão: Um Contrato Especial de Direito Público "Intuitu Personae"}

4. A concessão é uma delegação de poderes para a execução de um serviço público, que se caracteriza pelo fato de ser o concessionário um operador que atua de acordo com a regulamentação e sob a fiscalização do Poder Público. Etimologicamente, a concessão é uma cessão, na qual o cedente mantém a sua autoridade e sua responsabilidade, donde a composição da palavra (com + cessão) exclui a idéia de uma cessão simples, para enfatizar a parceria existente entre o Estado e a iniciativa privada. Ressalte-se que a delegação das atribuições ocorre sem prejuízo da responsabilidade do delegante.

5. Embora a concessionária seja pessoa jurídica de direito privado e o contrato a concessão se caracteriza como um contrato de direito público para o exercício de um serviço público. A melhor doutrina, tanto estrangeira como nacional, e a própria jurisprudência reconhecem a prevalência do interesse público que deve existir na concessão, sem prejuízo do resguardo dos direitos patrimoniais dos acionistas da empresa concessionária. Estes não podem, todavia, prejudicar o bom funcionamento do serviço. nem alterar as estruturas da empresa concessionária de modo a interferir na relação de direito público.

6. Neste sentido, a doutrina tem estudado os chamados contratos de colaboração entre a administração e os particulares, distinguindo a colaboração por atividade paralela da colaboração por participação. A primeira, que abrange por exemplo o estabelecimento de ensino, se caracteriza por uma atividade exercida pelo particular em seu próprio nome e no interesse tanto seu como do Estado. Ao contrário, na colaboração mediante participação voluntária, não se trata do exercício privado de uma função pública, mas sim da integração do particular na organização administrativa, ou seja na prestação dos serviços pelo Estado.

7. Tem sido entendido que, na colaboração por participação, o concessionário está associado ao funcionamento de um serviço público.' Afirma-se, ainda, que "Trata-se do exercício público de atividades públicas por um sistema de direito público." 2

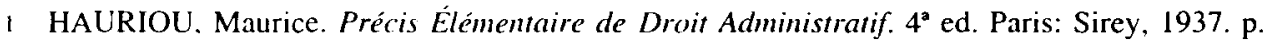
118.

2 MARIENHOFF, Miguel S. Tratado de Derecho Administrativo. $2^{2}$ ed. Buenos Aires: Abeledo Perrot, 197. T. II. p. 192, $\mathrm{n}^{\circ} 367$. 
8. Em monografia na qual trata da colaboração entre a administração e os particulares, BERNARD GÉNY esclarece que as concessionárias de serviço público são entidades que "na realidade se incorporam à administração pública, da qual se tornam, em certo sentido, se não juridicamente (pois mantêm seu caráter privado) ao menos praticamente um integrante da engrenagem da organização administrativa, obedecendo a uma sujeição mais acentuada de sua atividade em relação ao poder central." 3

9. No direito brasileiro, o caráter predominantemente público da concessão decorre do próprio texto constitucional de acordo com o qual a prestação do serviço público incumbe ao Estado, fazendo-o direta ou indiretamente (sob regime de concessão ou permissão) nos precisos termos do art. 175. Salientou pois o constituinte que mesmo prestado pelo concessionário, o serviço público é incumbência do Estado, podendo realizar-se mediante uma forma de cooperação na qual mantém o seu poder regulamentar e o dever de fiscalizar o concessionário.

10. Todas as definições da concessão esclarecem, por outro lado, que se trata de um contrato intuitu personae, no qual é fator relevante a escolha do concessionário, que depende de habilitação prévia e que pressupõe idoneidade financeira $e$ capacidade técnica. Efetivamente, na concessão, os capitais privados e a gestão empresarial são utilizados para realizar um serviço público, no interesse da sociedade e dos usuários. A qualidade do serviço depende, evidentemente, das condições pessoais do concessionário e de sua especialização.

11. A matéria é mansa e pacífica na Constituição, na lei, na jurisprudência e na doutrina. O texto constitucional reconhece o caráter especial do contrato de concessão (art. 175) e a lei determina que a fiscalização seja realizada pelo Poder Concedente, com a cooperação dos usuários (arts. $3^{\circ}$ e 30 da Lei $n^{\circ} 8.987 / 95$ ), cabendo ainda ao Poder Público autorizar a transferência não só da concessão, mas ainda do controle acionário da empresa concessionária (art. 27 da Lei $\mathrm{n}^{\circ} 8.987 / 95$ e art. 98 da Lei $n^{\circ}$ 9.472/97).

12. Esclarece Hely Lopes Meirelles que a "Concessão é a delegação contratual da execução do serviço, na forma autorizada e regulamentada pelo Executivo. $O$ contrato de concessão é ajuste de Direito Administrativo, bilateral, oneroso, comutativo e realizado "intuitu personae"" 4 (grifos nossos)

13. No mesmo sentido, tivemos o ensejo de escrever que "Não seria, no entanto, demasiado aditar ao conceito de concessão a característica 'intuitu personae', que the é inerente, diante, inclusive, da relevância que assume no ordenamento da matéria, com destaque para o disposto no art. 27 da lei, no tratamento da transferência da concessão e da mudança na composição do controle societário da concessionária". 5

3 GÉNY. Bernard, La Collaboration des Particulares avec L'administration, Paris, Sirey, 1930, p. 225.

4 MEIRELlES, Hely Lopes. Direito administrativo brasileiro. 26. ed. São Paulo: Malheiros, 2001. p. 358.

5 WALD, Arnoldo, MORAES. Luiza Rangel de. WALD, Alexandre de M. $O$ direito de parceria e a nova lei de concessões. São Paulo: Revista dos Tribunais. 1996. p. 102. 
14. Na doutrina estrangeira, também é pacífica a conceituação de contrato de concessão como sendo intuitu personce, como se verifica pelas lições, entre muitos outros. de BIELSA e de ESCOLA ${ }^{6}$ na Argentina, e de ANDRÉ DE LAUBADÈRE, na França. ${ }^{7}$

15. Tratando-se de um contrato realizado intuitu personae, é evidente que não pode haver a transferência da concessão, nem tampouco do controle da sociedade concessionária de direito e de fato sem prévia autorização do Poder Concedente, representado pela agência reguladora.

\section{Atos Societários e Atos Biface}

16. Como consequiência do caráter personalíssimo dos contratos de concessão, tanto na incorporação, como na cisão da sociedade, ou na mudança do seu controle, ao qual se refere expressamente a nossa legislação, temos um verdadeiro "ato biface", que é como tal reconhecido pela doutrina e pela jurisprudência.

17. Cunhamos a expressão "ato biface" em artigo publicado na Revista de Direito Mercantil. Industrial, Econômico e Financeiro ${ }^{8}$, caracterizando os atos de mudança de controle e de incorporação de bancos, terminologia que posteriormente foi consagrada na doutrina.

18. Entendemos que para ser eficaz, a modificação do controle acionário necessita de dois atos de natureza distinta, mas que somente produzirão os seus efeitos quando ambos forem realizados: um ato de direito comercial - a cessão de controle - e um ato administrativo - a autorização do concedente. São verdadeiros "irmãos siameses" que não podem ser dissociados, dando o ato administrativo validade à decisão de natureza comercial e funcionando como uma espécie de "blindagem", sem a qual a alteração é incompleta e não produz efeitos.

19. A doutrina brasileira tem admitido a existência de atos bifaces, que se caracterizam pela necessidade de serem praticados dois atos de natureza diversa, regidos por ramos distintos do direito, como é o caso da incorporação de banco ou da cessão de controle de empresa concessionária.

20. Tratando da matéria, na sua obra clássica, Hely Lopes Meirelles salientou que certos atos administrativos negociais dão ensejo à estruturação de atos bifaces:

6 ESCOLA, Héctor Jorge. Tratado integral de los contratos administrativos. Buenos Aires Depalma. 1979. v. 2, p. 33-34. Com o mesmo entendimento, MARIENHOFF. Miguel S. Tratado de Derecho Administrativo. Buenos Aires: Abelado Perrot. 1970. t. III-B, p. 613, e FIORINI. Bartolomé A. Manual de Derecho Administrativo. Buenos Aires: La Ley, 1968. t. I, p. 514.

7 LAUBADÉRE, André de. Traité élémentaire de droit administratif. 4. ed. Paris: L.G.D.J., 1967. p. $562, \mathrm{n}^{\circ} 1.035$.

8 WALD, Arnoldo. Aspectos Peculiares do Direito Bancário: O regime jurídico dos autos bifaces. Revista de Direito Mercantil. Industrial, Econômico e Financeiro. São Paulo, n 48, p. 5, out./dez. 1982. 
“Os 'atos administrativos negociais', que acabamos de ver, são normalmente seguidos de 'atos de Direito Privado', que completam o negócio jurídico pretendido pelo particular e deferido pelo Poder Público. E o que ocorre, p. ex., quando a Administração licencia uma construção, autoriza a incorporação de un banco, aprova a criação de uma escola ou emite qualquer outro ato de consentimento do Governo para a realização de uma atividade particular dependente da aquiescência do Poder Público. São atos 'bifaces'.

Os dois atos são distintos e inconfundíveis, mas permanecem justapostos um ao outro de modo indissociável. Dai porque não podem as partes Administração e particular - alterá-los ou extingui-los unilateralmente, sendo sempre necessária a conjunta manifestação de vontade dos interessados para qualquer modificação ou supressão do negócio juridico objetivado."

21. Hely Lopes Meirelles desenvolveu seu pensamento em parecer que deu a respeito da incorporação de banco, mas a sua lição se aplica também como uma luva à cessão de controle de empresa concessionária, que deve ser autorizada pelo Poder Concedente. Na realidade, a autorização do Concedente constitui um ato-condição para a realização da operação pretendida, a qual somente poderá ser efetivada na forma aprovada. Ao tratar do ato biface, o jurista entende que:

“(...) É um ato 'biface' que se forma com a justaposição da vontade da Administração à pretensão dos particulares. Ambas são distintas mas inseparáveis: aquela é regida pelo direito administrativo e esta pelo direito privado, mas uma não sobrevive sem a outra, e, assim sendo, para invalidar-se ou alterar-se o negócio há que se desconstituir ou modificar, primeiro, o ato administrativo, para depois alterar o 'ato comercial', pois aquele é que plasma este e o acompanha em todas as suas mutações." ${ }^{10}$ (grifos nossos)

22. E ainda que:

“Essa interferência de atos administrativos em negócios particulares e vice-versa é corrente no Direito Público, como nos informam os mais autorizados pubiicistas pátrios e estrangeiros (cf. Rui Cirne Lima, in RDA 62/1; Lafayette Pondé, in RDA 63/16; Seabra Fagundes, in RDA 78/1; Caio Tácito, in RDA 114/465; Hely Lopes Meirelles, Estudos e Pareceres de Direito Público, 1/43; Arnoldo Wald, "Aspectos Peculiares do Direito Bancário - O regime jurídico dos atos bifaces", RDM 48/5. Na doutrina estrangeira, v.: Jèze, Contrats de l'Administration, Paris, 1934, 1/3; Lauba-

9 MEIRELLES, op. cit. p. 183.

10 MEIRELLES, Hely Lopes. Estudos e pareceres de direito público. São Paulo: Ravista dos Tribunais, 1984. v. 8. p. 309-310. 
dére, Contrats Administratifs, Paris, 1956, 1/115; Marienhoff. Tratado de Derecho Administrativo, Buenos Aires, 1966, III/20.), como também a nossa jurisprudência reconhece e admite a ingerência do Poder Público em negócios civis ou comerciais (STF, RDA 46/192, e tb. no Agr. 74.195-0/MT, j. 4.12. 78; TFR, MS 80.938-RJ, publ. 24.8. 78, Al 43.784-RJ e 43.785 RJ, j. 57.5.83, DJU 1.9.93; TJSP, AgRg 32.172, j. 14. 4.83, RT 574/63)." "

23. O aspecto constitutivo da autorização administrativa, quando essencial para a validade do ato, como ocorre na transferência do controle acionário, tem sido enfatizado pela doutrina, que considera que, em tais hipóteses, o papel do Estado ainda é mais importante do que se ele fosse parte no contrato. É o que salienta Ernst Forstoff ${ }^{12}$, para quem a autoridade, ao validar o contrato, também deverá intervir quando o mesmo for modificado.

24. Ora, aplicando-se tais princípios, verifica-se que, dada a concessão a determinado concessionário, qualquer modificação relevante na sua estrutura, por qualquer meio ou forma, só pode ocorrer com a intervenção do Estado, ou seja, no caso, da agência reguladora.

25. A afirmação se aplica quer o controle seja modificado por vontade das partes, ou por decisão da Justiça Estadual, apesar de ser esta incompetente para alterar ou anular decisão de autoridade federal, não podendo modificar o controle do concessionário em processo no qual a agência reguladora não é parte. E se for parte, a competência será da Justiça Federal.

\section{Da Atuação e Intervenção do Poder Concedente}

26. Há consenso quanto ao fato de ser mantido pelo Poder Concedente o poder de regulamentação do serviço público, cuja titularidade mantém, transferindo-se tão-somente a execução, ou seja a gestão do serviço ${ }^{13}$.

27. Por sua vez, a Lei $n^{\circ} 8.987$ previu várias as formas de controle abrangendo a fiscalização, a competência do Poder Concedente para cumprir e fazer cumprir as disposições regulamentares e as cláusulas contratuais e zelar pela boa qualidade do serviço, assim como um amplo direito de acesso a todos os dados relativos à empresa concessionária e às obras, equipamentos e instalações (artigos $3^{\circ}, 29 ; 30$ e 31 ).

28. Em decorrência, reconheceu que:

11 MEIRELLES, Hely Lopes. Direito administrativo brasileiro, 24. ed. São Paulo: Malheiros, 1999. p. 174.

12 FORSTOFF. Ernst. Traité de droit administratif allemand. Tradução francesa por Michel Fromont. Bruxelas: Bruylant, 1969, p. 424. [Original em alemão].

13 ESCOLA. Héctor Jorge. Tratado Integral de los Contratos Administrativos. Buenos Aires: Depalma. 1979. V. II, parte especial, p. 78-79. 
"O exercício desse poder de direção e controle constitui um "poder-dever" da Administração, ao qual ela não pode furtar-se, sob pena de responsabilidade por omissão." 14

29. Quando existem normas legais e regulamentares referentes ao controle acionário da empresa concessionária, que também teve previsão no edital da licitação, um dos aspectos da fiscalização do Concedente é o que se refere ao exercício do poder de decisão na sociedade que realiza o serviço público. A matéria pode ser relevante seja para manter o statu quo existente no momento da outorga da concessão, seja para impedir que empresas sob o mesmo controle violem as normas estabelecidas para garantir a adequada competição no sistema. Foi aliás o que ocorreu, no passado, no caso da CRT, que ensejou medidas administrativas e providências judiciais por parte da ANATEL. Cabe aliás lembrar que, no mencionado caso, no qual se discutia o controle da CRT, a União Federal interveio como assistente com base no art. $5^{\circ}$ da Lei $n^{\circ}$ 9.469/97, esclarecendo, nas razões de agravo regimental, que apresentou, em 7.8.2000, interposto perante o Tribunal Regional Federal da $4^{a}$ Região que:

" O objeto do presente pedido de suspensão diz respeito a Ação Civil Pública ajuizada em face da Agência Nacional de Telecomunicações - ANATEL, Autarquia Federal Especial, criada pela Lei $n^{\circ} 9.472$, de 16 de julho de 1997.

Com efeito, ainda que o parágrafo único do art. $5^{\circ}$ da Lei $n^{\circ} 9.469 / 97$ não exija a demonstração de interesse jurídico, impede salientar que a intervenção da União se impõe pela presença, no centro da discussão travada na Ação Civil Pública em tela, de questão que, diretamente relacionada à prestação, regulamentação, organização e exploração dos serviços de telecomunicações, envolve grande repercussão jurídico-econômica." 15

30. No julgamento do mencionado Agravo foi reconhecida a legitimidade da intervenção da União no acórdão da $4^{2}$ Turma de 29.8.2000 do mencionado tribunal, cuja ementa é a seguinte:

“COMPETÊNCIA. LIMINAR EM AÇÃO CIVIL PÚBLICA. 'FUMUS BONI IURIS' E 'PERICULUM IN MORA'. AUSENNCIA.

I - COMPETEN CIA. Estando envolvidos na lide a União e Estado-membro a competência só é descolada ao STF quando se tratar de questão que envolva risco de quebra do pacto federativo. INOCORRÊNCIA.

2 - 'FUMUS BONI IURIS' IMPRESENTE.

DEVER DE FISCALIZAÇÃO SOBRE A CONTROLADORA. A ANATEL cumpriu com os atos legais capazes de demonstrar sua fiscalização sobre a controladora da CRT, chegando até a intervenção. Afastada a omissão.

14 DI PIETRO, Maria Sylvia Zanella. Parcerias na Administração Pública. São Paulo: Atlas. 1996. p. 55 .

15 Agravo Regimental do Agravo de Instrumento $n^{\circ}$ 2000.04.01098103-2/RS do TFR da $4^{a}$ Região. 
PREVALENCIA DO INTERESSE PÚBLICO SOBRE O PRIVADO. A decretação de caducidade da concessão implicaria na descontinuidade do serviço prestado em detrimento do interesse público que é a manutenção do mesmo.

PODER DISCRICIONÁRIO DA ADMINISTRAÇÃO. Deverão ser atendidos, na aplicação das sanções, os critérios de conveniência e oportunidade. $" 16$

31. No âmbito do setor de telecomunicações, por exemplo, para que se possa definir o campo de atuação da ANATEL é preciso que alguns fatos, desde a sua criação, sejam considerados, levando em conta os aspectos da reorganização dos serviços de telecomunicações empreendidos pelo Estado.

32. Por ocasião da nova organização dos serviços de telecomunicações, efetuada pelo Governo Federal, em dezembro de 1996, o Ministério das Comunicações deflagrou um amplo processo, com a edição de regras inspiradas nos aspectos essenciais da economia do setor, da estrutura de mercado que se pretendia modificar e da estratégia de introdução da competição na prestação de serviços. É o que foi enfatizado na introdução da Exposição de Motivos do Projeto de Lei de dezembro de 1996, visando atender ao disposto na Emenda Constitucional $n^{\circ} 8$, de agosto de 1.995, quanto à edição de legislação própria sobre a organização dos serviços de telecomunicações, considerando que a exploração de tais serviços é de competência da União, exercendo-se diretamente ou mediante outorga de concessão, permissão ou autorização.

33. O atendimento às premissas básicas do Projeto impuseram respeito ao princípio que rege a organização dos serviços de telecomunicações, ou seja, o da livre, ampla e justa competição, de forma que ao Poder Público coube impedir a monopolização do mercado, reprimindo condutas que possam consubstanciar infrações à ordem econômica, no intuito de buscar sempre o acesso amplo aos serviços de interesse coletivo, consoante ainda destaca a Exposição de Motivos do Projeto.

34. Neste passo, evidenciamos que a ANATEL, além de se incumbir da edição das normas e da responsabilidade pela outorga de concessões e permissões, deve atuar também na fiscalização preventiva e repressiva dos atos empresariais das concessionárias de serviços de telecomunicações, especialmente dos atos que evidenciem práticas contrárias à ordem estabelecida pela regulamentação vigente.

35. Este papel que lhe é conferido é o princípio consagrador da atuação do Estado ao controlar as atividades empresariais com vistas ao interesse geral, para que a agência promova o controle das condutas das operadoras detentoras de outorga, em virtude de concessão ou de permissão, adotando medidas transparentes.

36. A lei do regime de concessões - Lei $n^{\circ} 8.987 / 95$-, ao cuidar dos encargos do Poder Concedente, em seu art. 29 , não se afastou das colocações acima referidas e até veio reiterá-las, ao estabelecer que a entidade é competente para verificar a fiel 
observância das disposições regulamentares e contratuais, exercendo os deveres de fiscalização.

37. Da regulamentação dos serviços de Telecomunicações constam regras de apuração, pela ANATEL, acerca de condutas empresariais que possam caracterizar alterações do controle das concessionárias, segundo critérios preestabelecidos. Neste sentido, conceituou-se o que se entende pelas palavras controle e controladora e definiu-se os seus elementos, de modo a orientar o mercado brasileiro do segmento de telecomunicações, sempre com o intuito final de conservar a aplicação dos princípios da competitividade e da prestação do serviço adequado.

38. A conceituação de controle, na forma da Resolução ANATEL $n^{\circ}$ 101/99, para fins de apuração e de transferência do mesmo em empresas prestadoras dos serviços de telecomunicações, é abrangente e exemplificativa na medida em que abrange todo o campo societário e gerencial da empresa. Na prática, observa-se que o conceito legal de controle pode ser contemplado em diversas situações, seja em decorrência de medida judicial que possa alterar situação de fato ou de direito, seja por meio de estratégicas manobras societárias de quaisquer ordens, ou porque as mesmas podem ensejar a descaracterização da identidade original do grupo controlador, ou ainda impedir a condução dos negócios pelo titular do controle, e portanto prejudicar o exercício da exploração dos serviços públicos de telecomunicações.

39. Importa ressaltar que, para efeito do regulamento de apuração do controle, o funcionamento das empresas compreende, entre outros aspectos, o planejamento empresarial e a definição de políticas de cunho econômico e financeiro, como as de mercado, dentre outras.

40. À toda evidência, o que se deseja verificar é o reflexo empresarial das transformações de controle procedidas, que venham a se afastar das condições originais das concessionárias ao tempo da outorga, no que elas se refiram à gestão corporativa, encaminhando-se, inclusive, a idoneidade financeira e técnica do controlador, quer se trata de modificação superveniente das suas condições legais ou econômicas, quer haja transferência de direito ou de fato para um novo controlador.

\section{As Transformaçōes Societárias das Concessionárias no Setor de Telecomunicações}

41. No âmbito do setor de telecomunicações, ao tempo da outorga da concessão de serviços de telefonia celular, e mais precisamente quando várias empresas ou grupos de empresas se submeteram ao atendimento dos requisitos do Edital MC/BNDES $n^{\circ} 01 / 98$, as estruturas societárias foram compostas de maneira a observar os dispositivos editalícios, ou seja, tendo sido comprovadas e aceitas pela Comissão Julgadora da Licitação as configurações dos participantes e dos controladores e a sua total sintonia com os requisitos da licitação.

42. A aceitação dos termos e condições do contrato de concessão pelos participantes comprometeu-os a comunicar toda e qualquer transformação que afetasse as respectivas composições originais, com a finalidade, entre outras, de afastar práticas vedadas pela regulamentação de telecomunicações. A comunicação à ANATEL 
decorre do atendimento explícito do art. 97, parágrafo único, da Lei Geral de Telecomunicações, devendo efetivar-se previamente para a devida aprovação do órgão regulador, que pressupõe à manutenção das condições existentes no momento da licitação, tanto no que se refere à competitividade no mercado como a situação financeira do controlador e a manutenção e desenvolvimento da tecnologia utilizada.

43. Mudanças societárias que venham sendo realizadas, algumas inclusive com base em decisões judiciais liminares, e que contemplem, no tocante à estrutura de controle, direto ou indireto, das concessionárias, condições diversas das pactuadas na origem, exigem a análise prévia e a autorização da ANATEL, pois indiscutivelmente afetam o exercício do controle das mesmas, impactando todos os aspectos decisórios das concessionárias.

44. Se tais alterações não forem devidamente informadas à ANATEL e por ela aprovadas, estarão as concessionárias deixando de cumprir uma das obrigações fundamentais do contrato de concessão, que é a de manter, durante todo o período da exploração dos serviços, as condições de habilitação exigidas na licitação.

45. A fiscalização da exploração dos serviços de telecomunicações, pelo órgão regulador, deve abranger todos os aspectos negociais que possam afetar direta ou indiretamente os contratos de concessão. Cabe ter em consideração os princípios de competitividade e de manutenção das condições licitatórias de habilitação e qualificação, já abordados, assim como a forma de exercício do controle, seja diretamente pelo controlador, seja por intermédio de empresas holdings ou em virtude de acordo de acionistas.

46. A Resolução $n^{\circ} 001$, de 17.12.97, que aprovou o Regimento Interno da ANATEL, evidencia a existência de regras que permitem que áreas com poderes de fiscalização sobre os serviços de telecomunicações (Superintendências e seus Departamentos de Controle) acompanhem o cumprimento dos contratos, monitorando as suas prestações e apurando pari passu a observância dos atos normativos e obrigações assumidas das concessionárias e seus controladores. Podem também os referidos órgãos solicitar auditorias para levantar informações de interesse da agência.

47. Assim sendo, é poder-dever das Agências Reguladoras, cada uma na sua própria área de atuação, exercitar de ofício a fiscalização regularmente a ela atribuída, de maneira preventiva e corretiva, em quaisquer das hipóteses acima referidas. Somente assim cumprirá integral e efetivamente a missão que the foi confiada.

48. O que se exige, ao final, é que o órgão regulador atue com a acuidade e diligência, de acordo com sua competência, estabelecida na órbita de verdadeiras missões, como foram concebidas no processo de reestruturação dos respectivos mercados.

\section{Problemas Societários e Intervenção da Agência Reguladora}

49. Embora, em tese, os problemas referentes ao controle acionário sejam questões de direito privado, que se resolvem na Justiça Estadual, as repercussões 
que podem ter no caso de empresa concessionária justificam a intervenção do Poder Público.

50. Além da hipótese da CRT já referida, tem sido este o entendimento dos tribunais em relação aos casos nos quais há interesse do Banco Central, para salvaguardar a higidez das instituições financeiras.

51. Assim, em despacho proferido em Agravo Regimental pela Câmara Especial do Tribunal de Justiça de São Paulo, foi reconhecido, já na ementa, o interesse do Banco Central, por se tratar de discussão sobre aumento de capital de instituição financeira, esclarecendo a decisão:

"Desde que manifestado interesse da União Federal ou de suas autarquias no processo cessa a competência da Justiça estadual, sendo obrigatória a remessa dos autos à Justiça Federal, porquanto cabe a esta - e somente a ela-decidir se há ou não interesse federal a justificar o deslocamento da ação para o âmbito respectivo.

A medida cautelar liminarmente concedida aos acionistas minoritários em detrimento dos legítimos interesses dos demais acionistas pode ter seus efeitos sustados, porquanto as medidas cautelares, mesmo aquelas deferidas após cognição completa, não fazem coisa julgada, podendo a qualquer tempo ser revogadas ou modificadas." 17

52. No corpo do acórdão, datado de 26.1.1983, da lavra do Desembargador Andrade Junqueira, consta a justificativa da admissão do Banco Central no feito, com o decorrente deslocamento da competência, esclarecendo o relator:

"Aliás, o Banco agravante exibiu magníficos pareceres dos juristas Hely Lopes Meirelles e José Frederico Marques (fls.), ambos no sentido de que a intervenção do Banco Central do Brasil em um feito, onde se pretende o desfazimento de ato decorrente de sua competência, acarreta o deslocamento do processo para a alçada da Justiça Federal, porquanto o Banco Central do Brasil é a autoridade competente para autorizar a alienação a que alude o art. 255 da Lei das Sociedades Anônimas.

Resulta dai ser relevante o fundamento invocado pelo agravante para a concessão da medida liminar no caso presente, porquanto a medida cautelar liminar em primeira instância foi deferida por Juiz manifestamente incompetente, uma vez que o Banco Central do Brasil já havia pedido sua intervenção no feito, manifestando interesse no julgamento da causa, para o efeito de assegurar o cumprimento de suas determinações legais e para verificar a regularidade da sua execução, não sendo competente a Justiça estadual para decidir se há ou não interesse federal na espécie.

17 Agravo Regimental no Mandado de Segurança n $32.172-1$ In: Revista dos Tribunais, São Paulo, $n^{\circ} 574$, p. 63. 
No caso dos autos, por força de despachos proferidos por Juiz incompetente, acionistas representando coeficiente insignificante do capital social conseguiram medida liminares para evitar, por dois anos seguidos, que um estabelecimento bancário deixasse de atender às determinações baixadas pelo Banco Central do Brasil e da Comissão de Valores Mobiliários no sentido de aumentar o capital do Banco, atitude que, nessa inflação monetária galopante por que passa a Nação, pode acarretar, sem sombra de dúvida, até mesmo a falência do estabelecimento, em detrimento até dos próprios autores da demanda principal.

Está patente, aí, o interesse específico do Banco Central do Brasil em ingressar nos autos para a defesa de suas prerrogativas legais e para a verificação da regularidade dos atos que deferiu, intervenção que obriga à remessa dos autos à Justiça Federal." 18

53. Concluiu o acórdão decidindo que:

“Por todo o exposto, a Câmara Especial, por maioria de votos, dá provimento ao agravo para conceder medida liminar para o efeito de sustar os efeitos do despacho de primeira instância que justificou a propositura do presente mandado de segurança' e, por via de conseqüencia. para autorizar o Banco agravante a convocar assembléias gerais extraordinárias para as finalidades aludidas para dar cumprimento às determinações do Banco Central do Brasil', assim como a conseqüente averbação, ou registro, das atas perante a Junta Comercial. Custas a final." 19

54. Não há, assim, qualquer dúvida quanto ao poder-dever da Agência Reguladora que, garantindo o bom funcionamento dos serviços públicos, tem legítimo interesse em verificar quem exerce o controle direito ou indireto da empresa concessionária. Cabe-lhe examinar se houve ou não mudança de controle, em qualquer nível, avaliando a idoneidade financeira e técnica de quem exerce de fato o poder na sociedade concessionária, sob pena de responsabilidade do Poder Concedente, por omissão no exercício do seu dever de fiscalização.

\section{O Interesse da União}

55. Embora a competência para autorizar a modificação de controle seja da ANATEL, é evidente que a União tem incontestável interesse no feito, pois, nos termos do art. 21, inciso XI, da Constituição, com a redação que lhe deu a Emenda Constitucional $n^{\circ} 9$, cabe-lhe a função de "explorar, diretamente ou mediante auto- 
rização, concessão ou permissão, os serviços de telecomunicações, nos termos da lei".

56. Sendo pois a União a entidade incumbida de garantir ao público a prestação do serviço adequado no campo das telecomunicações, a mudança de controle do concessionário pode ameaçar a manutenção desse serviço, especialmente quando o novo controlador é, por exemplo, empresa estrangeira sem bens relevantes no Brasil, que não apresenta prova da sua idoneidade financeira, tendo, inclusive, deixado uma das suas subsidiárias recorrer à concordata no exterior, ou quando a imprensa internacional reconhece a sua insolvência.

57. Assim sendo, justifica-se a presença da União no feito com base no art. $5^{\circ}$, parágrafo único, da Lei $n^{\circ}$ 9.469/97, que tem a seguinte redação:

"Art. 50. A União poderá intervir nas causas em que figurarem, como autoras ou rés, autarquias, fundações públicas, sociedades de economia mista e empresas públicas federais.

Parágrafo único. As pessoas jurídicas de direito público poderão, nas causas cuja decisão possa ter reflexos, ainda que indiretos, de natureza econômica, intervir, independentemente da demonstração de interesse jurídico, para esclarecer questões de fato e de direito, podendo juntar documentos e memoriais reputados úteis ao exame da matéria e, se for o caso, recorrer, hipótese em que, para fins de deslocamento de competência, serão consideradas partes." (grifos nossos)

58. A apreciação do pedido de ingresso no feito é de competência exclusiva da Justiça Federal, a qual pode decidir sobre a existência ou não de interesse jurídico da União a justificar a sua intervenção, conforme entendimento do SUPREMO TRIBUNAL FEDERAL, no seguinte sentido:

"Recurso Extraordinário. Constitucional. Usucapião. Perímetro de Aldeamento Indígena. Manifestação de Interesse da União Federal. 'Incompetência da Justiça Comum para Avaliação do Pedido'.

I. Ação de reconhecimento de domínio sobre imóvel situado no domínio de aldeia indígena. 'Manifestação de interesse da União, perante a Justiça Estadual. Somente à Justiça Federal cabe avaliar a realidade ou não desse interesse'.

2. 'Incompetência da Justiça comum para exame da pretensão - Recurso conhecido e provido'." 20 (grifos nossos)

(RE n 222.152-SP, rel. Min. Maurício Corrêa, $2^{\mathbf{a}}$ Turma, DJ de 05.06.98)

20 No mesmo sentido: RE n 171.345, rel. Min. Carlos Velloso, DJ de 06.02.98; RE $n^{\circ} 198746-4$, rel. Min. Carlos Velloso. DJ de 23.05.97. 
VIII. A Diferença entre o "Amicus Curiae" e a Assistência Especialíssima (prevista pela lei $n^{\circ} 9.649 / 67$ )

59. Inspirando-se no direito norte-americano, introduzimos no Brasil, pela Lei $\mathrm{n}^{\circ} 6.616$ de 16.12.1978, que modificou a Lei $\mathrm{n}^{\circ} 6.385$ o amicus curiae, que no tocante ao mercado de capitais poderá esclarecer a Justiça sobre questões de direito ou de fato, podendo ou não assumir posição ao lado de uma das partes e funcionando como verdadeiro "amigo do juiz".

60. Distinta é a situação prevista pelo parágrafo único do art. $5^{\circ}$ da Lei $n^{\circ}$ 9.469/67, que cogita da possibilidade para as pessoas jurídicas de direito público de intervir em determinados feitos, ensejando inclusive o deslocamento da competência para a Justiça Federal, em casos nos quais existe interesse administrativo ou econômico, ainda que indireto, de evitar situações que possam prejudicar o bom funcionamento dos serviços públicos ou criar, por via oblíqua, ônus futuro para o Tesouro Nacional em processos nos quais não é parte, ensejando os conhecidos "esqueletos" que alguns governos herdaram dos seus antecessores.

61. Em tais casos, é legítimo e, em alguns casos, até obrigatório que o Poder Público venha a tomar a posição de parte, tratando-se de uma assistência especial de direito público que se equipara mas não se identifica com a prevista pela lei processual.

62. Efetivamente, em relação ao art. 50 do CPC, a jurisprudência tem entendido que a assistência só se justifica se houver interesse jurídico do terceiro, não bastando o simples interesse econômico.

63. A redação do parágrafo único do art. $5^{\circ}$ da Lei $n^{\circ} 9.469 / 97$ teve como finalidade permitir que as pessoas jurídicas de direito público resguardassem não só os seus interesses jurídicos, mas também os seus interesses econômicos tomando as providências necessárias para garantir o bom funcionamento das instituições.

64. Enquanto, no caso do art. 50, o tribunal aprecia o risco de prejuízo juridicamente relevante, ao contrário no caso da chamada "assistência especial" do art. $5^{\circ}$ parágrafo único, basta que a administração esteja defendendo posição por ela assumida no exercício de suas funções em relação à qual a cessão de direito pode ter reflexos econômicos mesmo que remotos, para que se justifique a sua presença no processo.

65. Em decorrência, tendo a Agência Reguladora decidido, no plano administrativo, qual a sistemática de controle que se exerce em determinado caso e, especialmente, havendo justo receio dos riscos que poderão advir, para o serviço público, em virtude da mudança de controlador, legitima-se a atuação da mesma para defender o interesse público.

66. Para tanto poderá agir administrativamente, suspendendo o direito de voto de determinados acionistas, como já o fez no passado, no caso da CRT, ou ser-lhe-á lícito intervir nos processos judiciais, como assistente especial equiparado à parte, podendo inclusive requerer a suspensão de medida liminar, a fim de evitar lesão à ordem ou à economia públicas. 
67. Evidenciados o poder-dever de intervenção do Poder Concedente e o interesse da União, a competência para o julgamento da matéria passa a ser da Justiça Federal, quer funcionem a União e a Agência Reguladora como litisconsortes do controlador por eles aprovado, quer sejam assistentes do mesmo.

68. Neste sentido, no caso dos atos bifaces, como o presente, novamente Hely Lopes Meirelles, ao tratar da atuação do Banco Central e da Comissão de Valores Mobiliários - CVM, que se encontram em posição simétrica em relação às Agências Reguladoras, esclarece o seguinte:

“27. A clareza do mandamento constitucional e a singeleza dos fatos dispensam considerações doutrinárias tendentes a demonstrar que, no caso, 'os atos administrativos praticados pelo Banco Central do Brasil (autorização) e pela Comissão de Valores Mobiliários (aprovação)', propiciadores da incorporação de um Banco por outro, 'teriam que ser desconstituidos pelo Judiciário por ilegalidade - e somente por ilegalidade' - 'para, após, decidir-se sobre a pretensão dos autores', acionistas preferenciais que postulam a compra de suas ações sem direito a voto, pelo mesmo preço das ações ordinárias com direito a voto. Mas, se a doutrina é dispensável por nada acrescer aos preceitos constitucionais invocados, útil será trazer à colação a jurisprudência concernente à competência da Justiça Federal para apreciar atos administrativos emitidos por autarquia federal e especialmente pelo Banco Central do Brasil e pela Comissão de Valores Mobiliários.

28. Em recente acórdão prolatado em 24.3.82, sobre o Juizo competente para invalidação de ato de autarquia federal, no conflito de jurisdição 6.273-3, o Plenário do Supremo Tribunal Federal decidiu que: 'É competente a Justiça Federal para a ação... porquanto o desfazimento do ato decorrente do seu poder... afeta substancialmente a esfera de competência dessa autarquia'.

E anteriormente já havia julgado a mesma Corte Suprema que: 'Após a Emenda Constitucional 1/69, pode o TRF conhecer de recurso de decisões de Juizes estaduais, para lhes reconhecer ou negar competência, e. nesse último caso, cassar a respectiva decisão. ' (STF, RTJ 78/401).

E mais este recentíssimo julgado: 'Somente à Justiça Federal, e não à Justiça local, compete emitir um juizo de valor sobre o interesse manifestado pela União' (RE 96.422-3-SP, $2^{a}$ Turma, Rel. Min. Cordeiro Guerra, in DJU de 30.4.82).

29. 'Dúvida não há, portanto, de que a Justiça Estadual é incompetente para decidir demanda em que são litisconsortes necessários' o Banco Central do Brasil e a Comissão de Valores Mobiliários, entidades a que a lei atribui poderes para autorizar e aprovar, respectivamente, a alienação, a aquisição de controle e a incorporação de um Banco comercial por outro. 
A competência em tal causa é, inquestionavelmente, da Justiça Federal." "1 (grifos nossos)

69. No mesmo sentido, José Frederico Marques, ao analisar algumas questões jurídicas relacionadas à alienação de controle de instituição financeira, tratando-se de companhia aberta, esclarece que:

" $\left.2^{\circ}\right)$ A autorização do Banco Central do Brasil e a aprovação da Comissão de Valores Mobiliários. respectivamente para a alienação de ações e incorporação do Banco em oferta pública, podem ser invalidadas ou desconsideradas pelo Poder Judiciários, sem o chamamento dessas autarquias à lide?

(...)

A resposta à primeira indagação do segundo quesito tem que ser negativa. Sem que o Banco Central participe de processo em que se pleiteia ou se discute a respeito da autorização dele emana, não pode o Judiciário invalidá-la. Isto é, mais que óbvio, em razão do postulado do processo contraditório e do devido processo legal.

(...)

$\left.3^{\circ}\right)$ Qual é a Justiça competente para a desconstituição ou desconsideração do ato administrativo do Banco Central do Brasil e da Comissão de Valores Mobiliários?

(...)

No que tange ao terceiro quesito, certo é que provindo a autorização de Autarquia Federal, a competência é da Justiça Federal. (...)

$\left.5^{\circ}\right)$ Quais os órgãos judiciários com atribuição e competência para o processo e julgamento de causas em que haja interesses do Banco Central do Brasil?

(...)

A Justiça Federal é a única com competência e atribuição para as mencionadas causas. A competência é 'ratione personae', pois o Banco Central do Brasil é autarquia federal. Cuida-se, no caso, de competência absoluta, por decorrer da nossa organização federativa, em que os interesses da União e respectivas autarquias não podem ser apreciados e julgados exclusivamente pela magistratura federal. Refoge das atribuições das Justiças locais (salvo nos casos expressamente previstos na Constituição), processar e julgar litígios em que haja interesse de Autarquia Federal. (...)

21 MEIRELLES, op. cit. p. 320. 
$\left.8^{\circ}\right)$ A Justiça Estadual tem competência para declarar falta de interesse da União em alguna lide, ainda que essa lide tenha sido ajuizada na Justiça local?

(...)

A resposta ao $8^{\circ}$ quesito tem de ser negativa, mormente, hoje, em que a Jurisprudência do Supremo Tribunal Federal se tornou pacífica, no sentido de que "somente à Justiça Federal compete decidir sobre se há interesse da Uniäo na causa "( $R E n^{\circ} 94.645$, "in" $\left.R T J 99 / 1382\right)$ ". De igual orientação outros acórdãos do Pretório Excelso (RTJ, 51/387, 78/398, 79/356, 99/1.328).

\section{Conclusão}

(...)

Em razão da natureza e efeitos do ato autorizativo, é axiomático que o Banco Central tem interesse em todas as causas ou litígios referentes a negócios ou atos jurídicos derivados da autorização dele emanada, que a ela se liguem substancialmente, ou que dela resultem como consequiência imediata ou essencial. Dai por que o Banco Central, é, sempre, litisconsorte necessário nas mencionadas causas em demandas ou litígios.

(...)

Em todas as causas, em que o Banco Central deve ser litisconsorte necessário, a competência para o respectivo processo e julgamento, cabe, de modo absoluto, à Justiça Federal. Em conseqüência disso, é mais que óbvio apresentar-se como nula, qualquer decisão proferida por órgão da Justiça Estadual." (grifos nossos) $)^{22}$

70. Por sua vez, a Súmula 150 do STJ dispõe no seguinte sentido:

“ Compete à Justiça Federal decidir sobre a existência de interesse jurídico que justique a presença, no processo, da União, suas autarquias ou empresas públicas."

\section{Conclusão}

71. Assim sendo, entendemos que tratando-se de modificação de controle de empresa concessionária, por qualquer via, inclusive em virtude de decisões da Justiça Estadual, o Poder Concedente pode e deve intervir nos feitos para resguardar a sua competência, tratando-se de poder-dever que não pode deixar de exercer, sob pena de renúncia às funções básicas que lhe foram atribuídas pela Constituição, pela lei e pela própria regulamentação por ele baixada.

22 Marques, José Frederico. Pareceres. São Paulo: AASP. 1993, p. 43-50. 


\section{Índice Analítico da Revista de Direito Administrativo - RDA}

Vols. 140 a 186

Vols. 187 a 198

Vols. 199 a 210

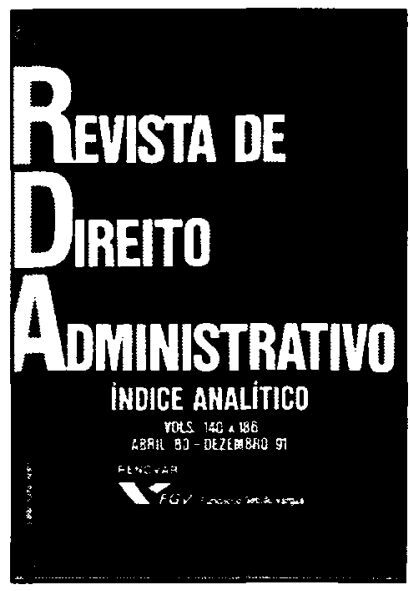

Indispensável como fonte de consulta para facilitar a localizaçāo, sem perda de tempo, dos respectivos assuntos apresentados na Revista de Direito Adininistrativo.

Ref. 0055

Ref. 0089

Ref. 0177

Cartonado

Form. 16x23

1991-1998

\section{Instituições Civis no Direito do Trabalho}

Alexandre Agra Belmonte

De conceitos atuais, de exemplos e com linguagem de fácil compreensão, não obstante a profundidade com que são tratados os temas estudados, trata-se de obra indispensável aos aspirantes da magistratura e procuradoria do trabalho, compreensiva de toda a matéria dos respectivos concursos, advogados, universitários, professores e todos os demais profissionais que militam na área trabalhista. O livro atenta para os fatos juridicos, porque ele dá uma perfeita noção do significado e alcance da obra, bem como de sua utilização prática.

Ref. 0078

Form. 14x21
Brochura 1997
366 págs.

$2^{2}$ ed.

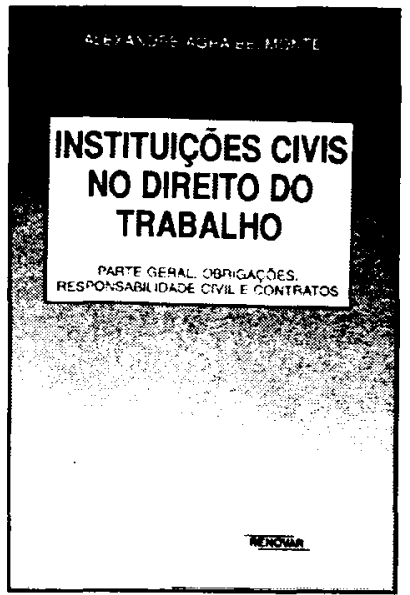

